\title{
DEFESAS DE MESTRADO - TURMA 2016 DO MPGEC - ESPM-RIO
}

Um olhar sobre o luxo: representações, significados e práticas entre um grupo de jovens moradores da Rocinha

A look at luxury: representations, significances and practices among a group of young people living in Rocinha

Autora: Daniela Jacques

Lattes: http://lattes.cnpq.br/7482673390883448

e-mail: danielajacques@uol.com.br

Orientadora: Sílvia Borges Corrêa

Lattes: http://lattes.cnpq.br/2577431414635655

e-mail: sborges@espm.br

\section{RESUMO}

A pesquisa intitulada "Um olhar sobre o luxo: representações, significados e práticas entre um grupo de jovens moradores da Rocinha" analisa as principais representações do luxo entre um grupo de jovens moradores da Rocinha, uma favela na zona sul da cidade do Rio de Janeiro. Esta pesquisa propõe uma investigação baseada em uma leitura fundamentada na perspectiva antropológica que compreende o luxo e o seu consumo como algo ativo, frequente e pertencente ao cotidiano. Assim, o luxo é interpretado dentro de uma visão que contempla aspectos simbólicos e práticos e desempenha um papel estruturador de valores: constrói identidades, regula relações sociais e define mapas culturais. A pesquisa teve como metodologia a etnografia, com a realização de observação participante e de entrevistas em profundidade, além da netnografia, com análises sobre as postagens dos jovens pesquisados nas principais redes sociais: Instagram e Facebook. Compreender como são construídas as práticas, os significados e as representações do luxo no âmbito do consumo entre um grupo de jovens moradores da Rocinha constitui-se como o objetivo geral desta pesquisa. Para além das representações, dos significados e das práticas relacionados ao luxo dos jovens pesquisados, os resultados revelam ainda a especificidade de ser morador(a) de favela, pois independente do que produzam, criem e consumam, ainda se sentem vistos pela sociedade de forma estigmatizada e veem na educação e no conhecimento o caminho para que se possa romper com o estigma de morador de favela.

Palavras-chave: luxo; consumo; etnografia; Rocinha; juventude

\section{ABSTRACT}

The research "A look at luxury: representations, significances and practices among a group of young people living in Rocinha" analyzes the main representations of luxury among 
a youth group living in Rocinha, a slum in the city of Rio de Janeiro. The research proposes an investigation based on an anthropological approach that understands luxury and its consumption as something active, usual and part of daily life. Luxury is interpreted from a perspective that contemplates symbolic and practical aspects, in which it fulfils a role of creating structured values: it builds identities, regulates social relations and defines cultural maps. Ethnography was the methodology that guided the research, with the use of observant participation and in-depth interviewing; netnography was also used, with the analysis of postings by the researched youths on the main social media: Instagram and Facebook. The overall objective of this research is to understand how practices, significances and representations of luxury are constructed in the realm of consumption among a group of young residents in Rocinha. In addition to representations, significances and practices of the researched youths related to luxury, the outcomes reveal the specificity of being a slum dweller, because regardless of their production, creation and consumption, they still feel themselves seen by society in a stigmatized way and they see in education and knowledge the path to remove the stigma of being a slum dweller.

Keywords: luxury; consumption; ethnography; Rocinha; youth

Marca como geradora de negócios para veículos de comunicação: estudo de caso da rede Atlântida FM

Brand as business generator for communication companies: the case study of the Atlântida FM network

Autor: Fernando Morgado Duarte Lattes: http://lattes.cnpq.br/6987795198218673

e-mail: contato.fernandomorgado@gmail.com

Orientadora: Lucia Maria Marcellino de Santa Cruz

Lattes: http://lattes.cnpq.br/0078280390470503

e-mail: lucia.santacruz@espm.br

\section{RESUMO}

Esta dissertação trata da extensão de marca no setor de mídia através do exemplo da Atlântida FM, rede regional de rádio presente nos estados do Rio Grande do Sul e de Santa Catarina. A partir dos métodos de análise documental e de estudo de caso, verifica se estender a marca de uma empresa de comunicação para novos mercados é alternativa eficaz ou não ao modelo de negócio tradicional da radiodifusão comercial. Ao final, conclui que tal estratégia traz resultados positivos para a Atlântida, mas aponta que a manutenção desse sucesso nos próximos anos depende de um crescimento mais elevado do investimento publicitário nos meios digitais, de forma a compensar o que ainda é garantido pelos meios analógicos. Caso contrário, 
os números de audiência registrados na Internet continuarão sendo empregados em projetos comerciais como complemento ao rádio $\mathrm{FM}$, que, a despeito de todas as mudanças no comportamento de consumo do público, ainda preserva patamares elevados de atração de ouvintes e de anunciantes.

Palavras-chave: economia criativa; economia da comunicação; extensão de marca; marca; radio

\section{ABSTRACT}

This dissertation deals with brand extension in the media sector through the example of Atlântida FM, a regional radio network present in the states of Rio Grande do Sul and Santa Catarina. From the methods of documentary analysis and case study, it verifies if extending the brand of a communication company to new markets is an effective alternative or not to the traditional business model of commercial broadcasting. In the end, it concludes that such a strategy has positive results for Atlântida FM, but points out that the maintenance of this success in the coming years depends on a higher growth of advertising investment in digital media, in order to compensate for what is still guaranteed by analogical means. Otherwise, audience numbers recorded on the Internet will continue to be used in commercial projects as a complement to FM radio, which, despite all the changes in consumer behavior, still preserves high levels of attraction for listeners and advertisers.

Keywords: creative economy; economy of communication; brand extension; brand; radio

Design de interação para produto de aproximação entre marcas e influenciadores digitais Interaction design for a product to connect brands and digital influencers

Autora: Helena Rodrigues de Paula

Lattes: http://lattes.cnpq.br/8084533769130049

e-mail: helenardp@gmail.com

Orientador: Eduardo Ariel de Souza Teixeira

Lattes: http://lattes.cnpq.br/9190622937276461

e-mail: eariel@espm.br

\section{RESUMO}

O objetivo central desta pesquisa é reunir informações e elementos para o planejamento e o desenvolvimento de um produto (interface) digital que possa estreitar as relações entre influenciadores digitais e marcas. Para isso, foram utilizados conceitos-chaves como redes sociais, influenciadores digitais, marcas, design de in- 
teração e usabilidade de interfaces. Também foram realizados estudos com um grupo de foco composto por usuários de redes sociais que não se sentiam influenciados por elas. Ao mesmo tempo, conduzimos entrevistas semiestruturadas com pessoas influenciáveis pelas redes sociais, com o intuito de compreender o comportamento desses perfis. Por fim, será estudado o comportamento de influenciadores digitais e seus recrutadores com o objetivo de entender o processo de escolha de perfil, recrutamento, seleção, acompanhamento e métricas, de forma a identificar as suas necessidades. Em seguida, os dados levantados serviram de insumos para a criação de personas e cenários que tornaram possível traçar um quadro completo a respeito do usuário final, o que nos permitiu projetar a ferramenta. A materialidade ocorreu pelo desenho do sitemap do produto, principais fluxos e wireframes das telas mais importantes com o foco de estreitar as relações entre influenciadores digitais e marcas.

Palavras-chave: influenciador digital, redes sociais, design de interação.

\section{ABSTRACT}

The aim of this research is to gather information and inputs for the planning and development of a digital product (interface) that will be able to improve the relationships between digital influencers and brands. To achieve that goal, we used key concepts such as social networks, digital influencers, brands, interaction design and interface usability. We also studied a focus group composed by users of social networks who did not feel influenced by them. At the same time, we did semi-structured interviews with people that are influenced by social networks, in order to understand the behavior of these profiles. Finally, we took into account the behavior of digital influencers and their recruiters in order to understand the process of how the profile is chosen, as well as the recruitment, selection, follow-up and metrics, in order to identify their needs. Then, the collected data served as input for the creation of personas and scenarios that made it possible to draw a complete picture about the main user, which allowed us to design the tool. The materiality occurred through the product sitemap design, as well as the main streams and wireframes of the most important screens. The objective was improving the relationships between digital influencers and brands.

Keywords: digital influencer, social networks, interaction design.

A arte em produtos de consumo em escala The art in scale consumables

Autor: Leonardo José Barreto Mattos Amato

Lattes: http://lattes.cnpq.br/5790197400106829

e-mail: contato@leoamato.com

Orientadora: Isabella Perrotta 
Lattes: http://lattes.cnpq.br/0405484529521542

e-mail: iperrotta@espm.br

\section{RESUMO}

O trabalho oferece uma reflexão sobre o processo de reprodução de obras de arte em produtos de consumo em escala, perpassando a temática da Economia da Cultura e o seu desdobramento em Capitalismo Artista, e a questão da reprodutibilidade da obra de arte e as formas de licenciamento autoral. Para tal, utilizou-se de pesquisa bibliográfica, entrevistas e análise empírica de exemplos existentes. Como materialidades, desenvolveu-se uma linha de produtos a partir do acervo do Museu de Arte do Rio de Janeiro - MAR, e também uma cadeia produtiva que percorre o caminho desde a obra de arte até o licenciamento e reprodução.

Palavras-chave: arte; reprodutibilidade; consumo.

\section{ABSTRACT}

The present work offers a reflection on the process of reproduction of works of art in consumer products in scale. Through the theme of the Economy of Culture and its transformation in Capitalism Artist, the question of the reproducibility of the work of art and the forms of licensing. For this, bibliographical research, interviews and empirical analysis of existing examples were carried out. As materialities, a product line was developed from the collection of the Rio de Janeiro Art Museum - MAR, and also a productive chain that runs the path from the work of art to licensing and reproduction.

Keywords: art; reproducibility; consumption.

O ensino centrado no aluno: a experiência dos Nativos Digitais em sala de aula e a relação com seus professores Imigrantes

Student-centered teaching: the Digital Natives experience in the classroom and the relationship with their Immigrants teachers

Autor: Luiz Eduardo Bordim

Lattes: http://lattes.cnpq.br/1979206296996371

e-mail: Ibordim@gmail.com

Orientador: Eduardo Ariel de Souza Teixeira

Lattes: http://lattes.cnpq.br/9190622937276461

e-mail: eariel@espm.br

\section{RESUMO}

$\mathrm{Na}$ atual reestruturação do mercado, com novas formas de organização da 
produção e do consumo e caracterizado mais pela lógica da inovação do que da reprodução, muitas das habilidades são redundantes. Como consequência, muitos países estão enfrentando uma crise de criatividade e uma guerra por talentos -fatores essenciais para o desenvolvimento da Economia Criativa. Nesse contexto, a educação, apesar de ser uma dos principal meios para qualificar as pessoas para a sociedade, está sendo questionada. Em um contexto de transformação, ela deve ser o motor do desenvolvimento, contribuir para a qualificação de novos cidadãos e colocar o aluno no centro da atenção. Para isso, entender as necessidades dos alunos, para que eles possam ser envolvidos de forma estimulante na sala de aula, é essencial. Ponto central nessa discussão, os Nativos Digitais são falantes naturais da linguagem digital dos computadores, video-games, celular e da internet. Nasceram e cresceram rodeados dessas tecnologias e pensam, processam informações e se comunicam de maneira diferente dos seus predecessores. Porém, apesar de sua importância, suas características não estão sendo consideradas nos métodos de ensino atuais, tornando as experiências educacionais atuais ruins. O tema desta pesquisa é a aplicação de conceitos de user experience em metodologias de ensino por escolas do ensino médio da cidade do Rio de Janeiro, visando o estimulo à criatividade, a inovação, ao pensar e ao fazer dos Nativos Digitais.

Palavras-chave: educação; nativo digital; experiência do usuário; tecnologia.

\section{ABSTRACT}

In the current market restructuring, featured by new forms of organizing production and consumption, and by the logic of innovation, a lot of needed skills are redundant. As a consequence, many countries are facing a crisis of creativity, and a war for talents -- key factors for the development of the Creative Economy. In this context, education, despite being one of the primary ways to qualify people for society, it's being challenged. In a transformation context, education should be the engine for development, contribute to new citizens' qualification and put the student at the center of the attention. For this, understanding the students' needs, so they can be involved in a stimulating way in the classroom, is essential. Central point in this, Digital Natives are natural speakers of computers, cell phones and the internet's digital language. Born and grew up surrounded by these technologies, they think and communicate in a different way than its predecessors. However, despite their importance, their characteristics are not being considered for nowadays teaching methods, making the current educational experiences bad. The theme of this research is the application of user experience concepts in teaching methodologies by high schools in Rio de Janeiro city, aiming to stimulate Digital Natives's creativity, innovation, thinking and doing.

Keywords: education; digital native; user experience; technology. 
Aplicação da metodologia Design Science Research na indústria do carnaval: A gestão dos métodos e processos de criação coletiva na fábrica do carnaval sob a ótica do design.

Application of the methodology Design Science Research in the carnival industry: The management of the methods and processes of collective creation in the carnival factory from a design perspective.

Autor: Marcos Aurélio Machado dos Santos

Lattes: http://lattes.cnpq.br/0545953995036128

e-mail: marcos.machado@espm.br

Orientadora: Eliana de Lemos Formiga

Lattes: http://lattes.cnpq.br/0699003375508032

e-mail: eformiga@espm.br

Co-orientador: Paulo de Oliveira Reis Filho

Lattes: http://lattes.cnpq.br/1380458804183151

e-mail: pauloreis@espm.br

\section{RESUMO}

O presente trabalho busca compreender como se dá o processo de criação coletiva da fábrica do carnaval sob a ótica do Design. Visa também identificar e mapear os saberes tácitos envolvidos nestes processos e estudar as formas de como transformá-los em conhecimento explícito.

Desta forma foi aplicada a gestão do conhecimento aliada à metodologia Design Science Research com foco na estratégia de estudo de caso na Cidade do Samba. Como resultado, foi desenvolvido um "Artefato" como um modelo de fluxograma da cadeia criativa/produtiva da fábrica do carnaval.

Palavras-chave: Criação Coletiva, Carnaval, Design, Gestão, Cadeia Produtiva, Cidade do Samba.

\section{ABSTRACT}

This study intends to understand how the process of collective creation of (Brazilian) carnival factory happens from the Design perspective. It also intends to identify and map the unspoken knowledge involved in these processes, and study the ways to turn them into explicit knowledge. Taking it into consideration, knowledge management was applied along with Design Science Research methodology, focusing on the strategy of case study at Cidade do Samba (Samba City). As a result, an "Artifact" was developed as a flowchart model of the creative/productive chain of carnival factory.

Keywords: Collective Creation, Carnival, Design, Management, Productive Chain, Cidade do Samba. 
Acting do personagem em animação e o processo de produção

Acting of character in animation and the production process

Autor: Maurício Vidal

Lattes: http://lattes.cnpq.br/1824697558484483

e-mail: mvidal2014@gmail.com

Orientador: Leonardo Marques de Abreu

Lattes: http://lattes.cnpq.br/8226912747072221

e-mail: Imarques@espm.br

\section{RESUMO}

O estudo tem como proposta uma investigação no campo da utilização das técnicas de acting de artes cênicas na criação de cenas de animação em produções para cinema, televisão ou novas mídias. Após o surgimento da $2^{\mathrm{a}}$ Era de Ouro da Animação, em meados dos anos 1990, com o lançamento do filme "Toy Story", a técnica de animação digital passou a ganhar espaço nas produções e efeitos do cinema. O desenvolvimento da utilização dessa técnica ocorreu durante a mesma época em que a internet se estabeleceu como meio de comunicação para todas as parcelas da sociedade. Através de vídeos e treinamentos on-line, bem como nos extras de filmes animados, percebe-se um crescimento na discussão e utilização de técnicas de acting como parte integrante do processo de produção para animação, mesmo tendo os princípios da animação tradicional por trás do sucesso dos filmes de animação digital. A metodologia de análise qualitativa utilizada foi a técnica de Análise do Conteúdo, seguindo o modelo de Laurence Bardin (1988), que permite a inferência (deduzir de maneira lógica) de conhecimento sobre o emissor ou sobre o destinatário da comunicação. O corpus da pesquisa foi composto por experientes e premiados animadores brasileiros. Procuramos apresentar um panorama do processo de produção de animação para ilustrar com mais clareza as questões voltadas para a inserção do acting em animação e as reflexões que possam ser geradas.

Palavras-chave: animação; acting; produção de animação.

\section{ABSTRACT}

The study aims to investigate the use of acting techniques, from the performing arts, in the creation of animated scenes in productions for cinema, television or new media. After the rise of Animation's 2nd Golgen Age, in the mid-1990s, with the release of 'Toy Story' movie, the digital animation technique came to gain space in movies productions and visual effects. The development of the use of this technique occurred as the internet was established as a media for the whole society. Through online videos and trainings, as well as animated movie extras, there is a growing discussion and use of acting techniques as part of the production process for animation, even though the principles of traditional animation remain behind the success of digital animation movies. The qualitative methodology used was the 
Content Analysis technique, following the model of Laurence Bardin (1988) that allows the inference of knowledge about the sender or the recipient of the communication. The corpus of the research was composed by experienced and award-winning Brazilian animators. We propose an overview of the animation production process to more clearly illustrate the issues related to the insertion of acting in animation and the reflections that can be generated.

Keywords: animation; acting; producing animation.

Entre capas e capistas: Um olhar sobre a prática do design de capas de livros

Between book covers and cover art designers - A look at the practice of book covers design

Autora: Nathalia Barone Lima

Lattes: http://lattes.cnpq.br/3130553712566155

e-mail: nathaliabarone@gmail.com

Orientadora: Eliana de Lemos Formiga

Lattes: http://lattes.cnpq.br/0699003375508032

e-mail: eformiga@espm.br

\section{RESUMO}

O trabalho busca compreender os processos de criação dos capistas brasileiros atuantes hoje no mercado, além de mapear onde e como estão inseridos na cadeia produtiva do livro. A coleta de dados foi feita por meio de pesquisa qualitativa através de entrevistas individuais semi-estruturadas registradas em vídeo. A análise dos resultados indicou pontos onde estes profissionais podem melhorar na relação com as editoras e pontos onde novos capistas podem usar como exemplo de práticas para se alcançar bons resultados. Em consequência foi desenvolvido um produto que é um livro que contém as entrevistas transcritas.

Palavras-chave: capa de livro; capista, design editorial.

\section{ABSTRACT}

The present work seeks to understand the creative process of the Brazilian cover art designer who are active in the market today, as well as to map where and how they are inserted in the book production chain. Data collection was done by qualitative research through semi-structured individual video interviews. The results' analysis indicated points where these professionals can improve their relationship with the publishers and points where new cover art designer can use as examples of practices to achieve good results. As a consequence a product has been developed which is a book with the transcribed interviews. 
Keywords: book cover, cover art designer, editorial design.

Economia Criativa no Rio de Janeiro: panorama e proposta de um evento na relação hélice tríplice

Creative Economy in Rio de Janeiro: overview and an event proposal in the Triple Helix

Autora: Patricia Cardoso Machado

Lattes: http://lattes.cnpq.br/2275025027830795

e-mail: patricia@popmkt.com.br.

Orientadora: Veranise Jucubowski Correia Dubeux

Lattes: http://lattes.cnpq.br/1706093099357760

e-mail:vduebx@espm.br.

\section{RESUMO}

O conceito de Economia Criativa deriva do termo Indústria Criativa e vem sendo discutido no mundo como uma oportunidade para países em desenvolvimento prosperarem no campo da cultura, política e tecnologia. Esta dissertação apresenta uma pesquisa sobre os eventos realizados no Rio de Janeiro que tenham no tema ou no conteúdo do evento o termo Economia Criativa no período de janeiro de 2014 a junho de 2017. O referencial teórico apresenta uma revisão na literatura sobre os temas: Economia Criativa, Eventos e Tríplice Hélice. Em seguida, identifica os eventos que contenham em seu título ou em seu conteúdo o termo Economia Criativa, ao longo dos três últimos anos e meio, ou seja, de janeiro de 2014 a junho de 2017. A pesquisa observa se estes eventos tiveram entre os palestrantes a integração entre os setores público, privado e acadêmico. Ao final, sugere um evento que una os setores público, privado e acadêmico com objetivo de criar conexões em prol da cidade do Rio de Janeiro.

Palavras-chave: Economia Criativa, Eventos, Hélice Tríplice.

\section{ABSTRACT}

The concept of Creative Economy derives from the term Creative Industry and has been discussed in the world as an opportunity for developing countries to thrive in the field of culture, politics and technology. This dissertation presents a research about the events held in Rio de Janeiro that have as theme or in the content of the event the term Creative Economy from January 2014 to June 2017. The theoretical framework presents a review in the literature on the themes: Creative Economy, Events and Triple Propeller and Events. It then identifies the events that contain the term Creative Economy over the last three and a half years from January 2014 to June 2017. It investigates whether these events had among 
the speakers the integration of the public and private. At the end it suggests an event that unites the public, private and academic sectors with the objective of creating changes in the structures of events, in order to create interaction between sectors.

Keywords: Creative Economy, Events, Triple Helix.

Sistema gerencial para eventos: proposta de um sistema para integrar informações e gerar indicadores para o mercado de entretenimento Management system for events: Proposing a system to integrate information and generate indicators for the entertainment market

Autor: Rafael Liporace de Souza Pereira

Lattes: http://lattes.cnpq.br/5564242513453807

e-mail: rafa@agenciaavera.com.br

Orientador: Daniel Kamlot

Lattes: http://lattes.cnpq.br/1863175020067147

e-mail: dkamlot@espm.br

\section{RESUMO}

O estudo visa analisar a viabilidade comercial e financeira do programa de gestão do empreendimento SGE (Sistema Gerencial para Eventos), que é um software gerencial integrado para o setor de entretenimento, cujo protótipo será apresentado como produto associado ao presente trabalho.

A proposta é ser mais que apenas um sistema gerencial entre tantas opções ofertadas, apresentando-se como um produto focado em um relevante nicho que não possui ainda nenhum sistema adaptado às suas reais necessidades empresariais.

Baseado na realidade da cidade do Rio de Janeiro, o plano de negócios da SGE surgiu da necessidade do mercado de entretenimento em agrupar as informações gerenciais espalhadas em diversos sistemas independentes, com isso visando a que fosse possível a obtenção de histórico, comparativos e principalmente indicadores para um mercado que a cada dia cria mais relevância no país e vem se profissionalizando ano a ano.

Palavras-Chave: sistema, software, aplicativo, controle, gerencial, entretenimento, eventos.

\section{ABSTRACT}

This study analyzes the commercial and financial viability of SGE project management program (Management System for Events which is an integrated management software for the entertainment industry. 
The proposal is to be more than just a management system among many options offered, presenting itself as a focused product in a relevant cluster that does not have any system adapted to their real business needs.

Based on the reality of Rio de Janeiro, SGE's business plan arose from the need of the entertainment market to group the management information spread across several independent systems, with the aim of obtaining historical, comparative and mainly indicators for a market that every day creates more relevance in the country and has been professionalizing year after year.

Keywords: System, Software, Apps, Control, Management, Entertainment, Events.

Memória da Roda cultural do Terreirão: projeto de capacitação visual para registros da memória de um evento do Hip Hop carioca Memory of Roda Cultural do Terreirão: visual training project for the record of the memory of a carioca Hip Hop event

Autor: Ricardo Pimentel Lattes: http://lattes.cnpq.br/1716230564508853

E-mail: rpimentel@espm.br

Orientadora: Mirella De Menezes Migliari

Lattes: http://lattes.cnpq.br/1182036061061100

e-mail: migliari@espm.br

\section{RESUMO}

Esta pesquisa levantou dados que permitiram a montagem eficaz de um programa de curso de iniciação fotográfica ministrado sobre câmeras instaladas em smartphones, que será oferecido gratuitamente aos participantes de um dos eventos do movimento Hip Hop carioca, batizado como Roda Cultural do Terreirão, que acontece mensalmente no Recreio dos Bandeirantes, zona oeste do Rio. O objetivo geral é preservar a memória visual desse evento, através da capacitação de seus participantes pelo referido curso, para que se sintam motivados a participar da produção de um banco de imagens colaborativo, com a melhor qualidade possível, que por sua vez possa ser útil como fonte de pesquisas e de materiais para divulgações artísticas e sociais, para todos os públicos ligados ao citado movimento, especialmente aos que fazem parte de seus pilares artísticos. Em função da originalidade do campo pesquisado, a metodologia adotada necessitou de flexibilidade e sustentou-se sobre características de pesquisas etnográficas e de pesquisa-ação, sem mergulhar integralmente nas duas e se iniciou pela imersão do pesquisador na área de recorte, em observações participantes, onde atuou como colaborador fotográfico do referido evento desde sua inauguração, em 2015. Esta etapa orientou a 
escolha criteriosa de um grupo fixo de colaboradores dentre os frequentadores da Roda e a partir daí foi realizada uma pesquisa de base qualitativa, com entrevistas semi-estruturadas com oito colaboradores selecionados. Os dados levantados foram cruzados com outros obtidos através de pesquisas documentais sobre programas de cursos fotográficos existentes, tanto presenciais quanto online, que serviram para a seleção de conteúdos que foram organizados na montagem de um protótipo de programa, que posteriormente foi colocado à prova pelo mesmo grupo anterior, atuando neste momento como grupo de testes, numa simulação da primeira aula do curso, devidamente documentada a fim de servir como roteiro de correções de rumos. Este projeto se insere na linha de design da educação, dentro do escopo da economia criativa e tal qual seu movimento inspirador pretende oferecer educação com arte, para que de uma forma criativa e motivadora venha somar-se ao extraordinário potencial criativo que o mesmo já detém, no sentido de produzir a memória de um movimento de cultura jovem de rua, que registre seu passado apontando ao seu futuro.

Palavras-chave: Fotografia com smartphones; Memória das Rodas Culturais; Banco de imagens do Hip Hop; Fotografia de arte de rua; Curso fotográfico com câmeras de smartphones.

\section{ABSTRACT}

This research gathers data that allow the effective assembly of a program of photographic initiation course taught on cameras installed in smartphones, which will be offered free of charge to participants of one of the events of the Rio Hip Hop movement, called Roda Cultural do Terreirão, which happens monthly in the neighborhood of Recreio dos Bandeirantes, west zone of Rio de Janeiro. The general objective is to preserve the visual memory of this event, through the training of its participants by the referred course, so that they feel motivated to participate in the production of a collaborative image bank, with the the best quality possible, which in turn can be useful as a source of research and materials for artistic and social dissemination, for all audiences linked to the aforementioned movement, especially those that are part of its artistic pillars. Due to the originality of the researched field, the adopted methodology required flexibility and was based on ethnographic research and action research characteristics, without immersing completely in the two, and began by immersing the researcher in the clipping area, in participant observations, where he served as a photographic collaborator of the event since its inauguration in 2015. This step guided the judicious choice of a fixed group of collaborators among Roda's customers, and from that point on, a qualitative research was conducted, with semi-structured interviews with each of the eight selected employees. The data collected were cross - checked with others obtained through documentary research on existing photographic course programs, both online and offline, that served to select contents that were organized in the assembly of a prototype program, which was subsequently tested by the same group, acting at this time as a test group, in a simulation of the first class of the course, duly documented in order to serve as a roadmap for course corrections. This project is part of the educational design line, 
within the scope of the creative economy and just as its inspiring movement does, seeks to offer education with art, so that in a creative and motivating way it can add to the extraordinary creative potential it already has, in the sense of producing the memory of a young street culture movement, that registers its past pointing to its future.

Keywords: Photography using smartphones; Memory of Hip Hop events; Hip Hop events collaborative image bank; Street art photography; Photographic course based on smartphone's cameras.

"A propaganda é nossa?": a decisão de publicitários de deixar agências cariocas para exercer a profissão nos mercados de São Paulo e de cidades criativas no exterior

"Advertising is Ours?": The decision of advertisers to leave cariocian agencies to exercise the profession in the markets of São Paulo and creative in other countries

Autor: Roberto Alvarez de Sá Filho

Lattes: http://lattes.cnpq.br/8413622444871303

e-mail: roberto.filho@espm.br

Orientador: Diego Santos Vieira de Jesus

Lattes: http://lattes.cnpq.br/6322729232079325

e-mail: divieira@espm.br

\section{RESUMO}

O objetivo desta dissertação é investigar por que publicitários decidiram deixar agências da cidade do Rio de Janeiro para exercer a profissão no mercado publicitário paulista ou de cidades criativas no exterior nas décadas de 2000 e 2010. Sustenta-se que a decisão desses profissionais de deixar agências de publicidade no Rio de Janeiro esteja relacionada à maior instabilidade financeira de tais publicitários diante da redução das receitas das agências locais e da diminuição dos gastos com publicidade por empresas contratantes diante do agravamento da crise político-econômica no município desde o início da década passada. Além disso, a decisão desses profissionais de deixar o setor da publicidade do Rio de Janeiro mostra-se ligada ao menor reconhecimento dos publicitários, por seus pares e pelo público, pela autoria de ideias nessa cidade em relação a São Paulo e cidades criativas no exterior.

Palavras-chave: Publicidade; Rio de Janeiro; profissionais criativos; crise política e socioeconômica 


\begin{abstract}
The aim of this dissertation is to investigate why advertising professionals decided to leave agencies of the city of Rio de Janeiro to work in the advertising market of São Paulo or creative cities abroad in the 2000s and 2010s. The main argument indicates that the decision of these professionals to leave advertising agencies in Rio de Janeiro is related to the greater financial instability of such professionals due to the reduction of revenues of local agencies and the decrease of advertising expenses by contracting companies in the light of the aggravation of the political-economic crisis in the city since the beginning of the last decade. Moreover, the decision of these professionals to leave Rio de Janeiro's advertising sector is linked to the lower recognition of advertising professionals, by their peers and the public, for the authorship of ideas in Rio de Janeiro in relation to São Paulo and creative cities abroad.
\end{abstract}

Keywords: Advertising; Rio de Janeiro; Creative professionals; Political and socioeconomic crisis

As novas formas de promoção e comercialização dos novos produtores de moda carioca

The new ways of promotion and commercialization of the new fashion producers in Rio

Autora: Sandra Sanches

Lattes: http://lattes.cnpq.br/4716585970595401

e-mail: sandrasanches@lsconteudo.com

Orientador: João Luiz de Figueiredo

Lattes: http://lattes.cnpq.br/9223950448656258

e-mail: joao.silva@espm.brr

\title{
RESUMO
}

A moda vive um período de transformação. Depois da escalada global da produção acelerada e consumo fácil de peças de vestuário, reproduzida em escala planetária, e baseada na redução constante dos custos - movimento já definido pelo mercado e em textos acadêmicos como fast fashion -, a moda se movimenta na direção de uma maior conscientização de seu papel social e, quase como uma antítese ao modelo industrial predominante, os novos produtores de moda, objetos deste estudo, desenham novas tendências, ancorados no intenso uso das plataformas digitais e consciência social. Questões culturais, éticas e de sustentabilidade se tornaram parte das novas linhas de produção e questionam o avanço irresistível de uma atividade que hoje movimenta bilhões em todo o mundo e que incorporou, nas últimas décadas, o lado mais selvagem da atividade comercial, o lucro a qualquer custo. O presente estudo trata das transformações que acontecem na atividade, a partir da incoporação, nos anos 2000, de novas tencologias e de novos modelos de 
promoção e venda nas plataformas digitais, baseados em novos valores e propósitos: colaboração, compartilhamento, ressignificação, sustentabilidade, customização, entre outros. Eles se tornam mais e mais acessíveis, à medida em que avança a organização da sociedade em rede, e garantem a base das mudanças em curso, impulsionadas, acima de tudo, pela desintermediação vigente no universo digital. O recorte geográfico para a pesquisa é o município do Rio de Janeiro por seu papel de vanguarda na moda e suas singularidades na conformação da história da mesma. Apesar da concentração da indústria em São Paulo, a cidade apresenta grande potencial criativo e carrega o histórico de ser a "grife" de maior aderência e recall da moda brasileira, devido principalmente à importância da moda de praia e ao valor agregado garantido pelo lifestyle carioca. Esta dissertação também aborda a relevância dos conceitos da Economia Criativa para a reinvenção do setor. As pesquisas de campo permitiram identificar no Rio um novo tipo de produtor de moda - surgido, principalmente, entre os jovens nativos digitais -, que está mudando a forma de criar, produzir, promover e distribuir seus produtos. Ao longo deste estudo, é possível perceber como os novos produtores de moda do Rio estão desenhando caminhos alternativos para a indústria. O novo modelo exibe valores como sustentabilidade, preços justos, valorização da cultura, promoção e venda desintermediadas e quer promover, além da geração de valor, a transformação do mundo. Ao final, esta dissertação conclui que os desafios são enormes e têm sido vencidos pela determinação, talento e criatividade dos novos produtores de moda carioca mas aponta para a necessidade de entidades de classe, órgãos públicos e empresas privadas apoiarem cada vez mais suas atividades. No atual cenário - em que a globalização e a crise econômica castigam a indústria da moda brasileira - eles surgem carregando oxigênio, renovação e alternativas para novas formas de produzir, promover e comercializar seus produtos. Necessitam de financiamentos, qualificação para gestão e apoio nos planejamentos de comunicação para expandirem sua atuação nas redes sociais e outras plataformas digitais e conquistarem, de fato, a relevância merecida no mercado da moda carioca e brasileira.

Palavras-chave: moda; economia criativa; novos produtores; novas tecnologias; sustentabilidade

\section{ABSTRACT}

Fashion has been going through a transformation period. After the global climb of accelerated production and easy consumption of garments, reproduções on a planetary scale, and based on constant cost reduction - movement already defined by the market and in academic texts, such as fast fashion. Fashion moves towards a better awareness of the social role and almost as an antithesis of the predominant industrial model, the new fashion producers, objects of this study, draw new trends, anchored in the intende use of digital plataforms and social awareness. Cultural, ethical and sustainable issues have become part of new production lines and question the irresistible advance of an activities that nowadays moves billions worldwide and which has incorporated in the last few decades, the wildest side of the business activities, profit at any cost. The present study deals with the changes 
that have been happening in the activity, from the incorporation in the years 2000 on, of new technologies as well as new promotion and sales models in digital platforms, based on new values and purposes: collaboration, sharing, resignification, sustainability, customization, among others....They have become more and more accessible, as it advances the organization of the society in networks, and they guarantee the basic for ongoing changes, driven by, above all else, the lack of intermediation in the digital universe. The geographic clipping for for the research is the municipality of Rio de Janeiro, for its vanguard role on fashion and its singularities in the conformation of its history. Despite the concentration of the industry in São Paulo, the city has a great creative potential and holds the historical traditional of being the most adherent "brand" and brazilian fashion recall, mainly due to the importance of beach fashion and the aggregated value entorses by the 'carioca' lifestyle. This dissertation also addresses the relevance of Creative Economy concepts for the reinvention of the sector. The field surveys allowed is to identify in Rio a new type of fashion producers emerged mainly among young digital natives - which has been changing the way of creating, producing, promoting and distributing their products. Throughout this study, it is possible to perceive how the new fashion producers in Rio have been designing new ways for industry. The new model displays values such as sustainability, fair prices, culture valorization, promotion and undetermined and that wants to promote besides the generation of value, the world transformation. At last, it is concluded in this dissertation that the challenges are huge and have been overcome by determination, talent and creativity of new producers of Rio de Janeiro fashion, but points to the news for class entities, public bodies and private companies support, each time more, there activities. In the corrent scenario - where the globalizariam and economic crises harm the Brazilian fashion industry - they arise by holding some oxygen, renovation and alternatives for new ways of producing, promoting and marketing their products. They need funding, qualification for managing and support in communication planning, in order to expand thir businesses in social networks and other digital platforms and to achieve, in fact, the deserved relevance in the Brazilian and 'carioca' fashion market, as well.

Keywords: fashion; creative economy; new producers; new technologies; sustainability.

\title{
A relação das produtoras de audiovisual com o mercado para captação de recursos e oferta de Product Placement e Branded Content
}

The relationship of audiovisual producers and the market for fundraising and Product Placement and Branded Content offering

\author{
Autora: Simone Terra \\ Lattes: http://lattes.cnpq.br/1555956397182862 \\ e-mail: simoneterra@sterra.com.br
}

Orientador: João Luiz de Figueiredo

Lattes: http://lattes.cnpq.br/9223950448656258 
e-mail: joao.silva@espm.br

\section{RESUMO}

O presente estudo trata das relações comerciais das produtoras de audiovisual com o mercado através da captação de recursos advinda das leis de incentivo, do Product Placement e do Branded Content, a partir dos métodos de análise secundária e pesquisa qualitativa com entrevistas semiestruturadas, realizadas junto a produtoras de audiovisual e empresas de mercado do eixo Rio/São Paulo, e explorando caminhos que possam, simultaneamente, melhor atender às expectativas do mercado - frente aos desafios que se fazem presentes na publicidade contemporânea - e potencializar as oportunidades de sustentabilidade das produtoras. Os resultados da pesquisa indicam a necessidade de uma postura inovadora e proativa em gestão estratégica por parte das produtoras, e a ampliação das oportunidades colocadas para o setor audiovisual, se buscado um movimento sinérgico com as transformações da Era Digital e as expectativas do mercado.

Palavra-chaves: cibercultura; setor audiovisual; product placement; branded contente, comportamento do consumidor; financiamento através de leis de incentivo.

\section{ABSTRACT}

The present study deals with the commercial relations of the audiovisual producers with the market through the funding of incentive laws, Product Placement and Branded Content, from the methods of secondary analysis and qualitative research with semistructured interviews carried out with producers of audiovisual and market companies of the Rio I São Paulo axis, and exploring ways that can simultaneously better meet market expectations - facing the challenges that are present in contemporary advertising - and enhance the sustainability opportunities of producers. The results of the research indicate the need for an innovative and proactive stance in strategic management by the producers, and the expansion of opportunities for the audiovisual sector, if a synergistic movement is sought with the transformations of the Digital Age and market expectations.

Keywords: cyberculture; audiovisual sector; product placement; branded content; consumer behavior; financing through incentive laws.

A marca Imperator: memória, cultura e experiência The Imperator brand: memory, culture and experience

Autora: Vera Zunino Rosa

Lattes: http://lattes.cnpq.br/7848043221469219

e-mail: vzunino@gmail.com 
Orientadora: Isabella Perrotta

Lattes: http://lattes.cnpq.br/0405484529521542

e-mail: iperrotta@espm.br

\section{RESUMO}

A pesquisa se volta para o estudo da marca Imperator Centro Cultural João Nogueira, enquanto identidade visual e valor simbólico, que atingem questões de memória e experiência. O que a marca representa e como a sua imagem é percebida e construída por seus frequentadores. A representação ligada à história do local, e sua importância para a região. O cine Imperator, motivo de orgulho dos moradores do bairro do Méier, no Rio de Janeiro, que imprimiu à zona norte um destaque em relação à cidade e sua modernização, serve de base para entender a importância que a marca gera e seu reflexo na memória do bairro. A memória afetiva, ligada à marca e a construção de novos significados pautados no presente do equipamento cultural, fazem parte desse estudo e das entrevistas feitas no local. A Semiótica, é a ciência que perpassa pelos diversos autores pesquisados e, torna possível levantar os componentes que conformam o significado da marca, a partir de seus aspectos qualitativos e analisar as associações que transpassam o sentido da visualidade e delineiam seu potencial simbólico. A percepção desses valores pode ser usada em estratégias de ações de branding.

Palavras-chave: Imperator, marca, memória, representação e valores simbólicos.

\section{ABSTRACT}

This research focus on the study of the brand Imperator Centro Cultural João Nogueira, as a visual identity, and its symbolic value, which reaches issues of memory and experience. What the brand represents and how its image is perceived and built by its customers. The representation linked to the history of the place, and its importance to the region. The Imperator cinema, is a source of pride for Méier district residents in Rio de Janeiro, which pushed the city towards the north and facilited its modernization, serves as a basis for understanding the importance that the brand generates and its reflection in the memory of the neighborhood. The affective memory, linked to the brand and the construction of new meanings based on the present of the cultural equipment, are part of this study and of the interviews done in the site. Semiotics is the science that permeates the various authors and makes it possible to invoke the components that shape the meaning of the brand from its qualitative aspects and to analyze the associations that transcend the sense of visuality and delineate its symbolic potential. The perception of these values can be used in branding action strategies.

Keywords: Imperator, brand, memory, representation and symbolic values. 
Espalha que é aula, junta que é livro: o Ensino da Economia Criativa no Ambiente Digital

Spread the classroom and gather in a book: The teaching of creative economy in the digital environment

Autora: Veronica Bidart de Castro Nelson Machado

Lattes: http://lattes.cnpq.br/7355074226704826

e-mail: koca@gruposal.com.br

Orientador: Fabro Steibel

Lattes: http://lattes.cnpq.br/0433208213067580

e-mail: ofabro@ofabro.com

\section{RESUMO}

Esta pesquisa analisa o ambiente da circulação de produtos da economia criativa no universo digital, a fim de propor uma metodologia ativa inovadora para sala de aula. A partir de um estudo de caso (i.e. uma disciplina de audiovisual da grade do curso de Publicidade e Propaganda da ESPM Rio), propomos uma metodologia que leva o aluno a criar e produzir produtos digitais em torno dos pilares da estrutura audiovisual, tornando-os conteúdos transmídia, com base nos conceitos de cultura participativa e hospitalidade. A oportunidade que percebemos é a de conectar e distribuir o conteúdo da disciplina de audiovisual através dos produtos da linguagem dos nativos digitais: postagens em redes sociais, vídeos, fotos, videographs, memes, dentre outros, transformando um ensino passivo em um processo ativo, motivado pelos novos caminhos da educação nas universidades. Como contribuição, elaboramos um referencial teórico que sustente a expansão do conteúdo acadêmico para outras mídias como metodologia e mostre que é possível espalhar conhecimento e o reunir ao final da jornada acadêmica o material espalhado pelas redes em um livro digital.

Palavras-chaves: economia criativa; educação; metodologias ativas; planejamento estratégico; cultura participativa; conteúdo transmídia; livro.

\section{ABSTRACT}

This research analyzes the environment of the circulation of products of the creative economy in the digital universe, in order to propose an innovative active methodology for the classroom. From a case study (ie an audiovisual discipline of the ESPM Rio Advertising and Advertising course), we propose a methodology that leads the student to create and produce digital products around the pillars of the audiovisual structure, making them transmedia contents, based on the concepts of participatory culture and hospitality. The opportunity we perceive is to connect and distribute the content of the audiovisual discipline through the products of the language of digital natives: posts in social media, videos, photos, video graphs, memes, among others, transforming a passive teaching into an active process, moti- 
vated by the new ways of education in universities. As a contribution, we have developed a theoretical framework that supports the expansion of academic content for other media as a methodology and shows that it is possible to spread knowledge and gather at the end of the academic journey the material spread by the networks in a digital book.

Keywords: creative economy; education; active methodologies; strategic planning; participatory culture; transmedia content; book.

Montagem e Tecnologia: Efeitos visuais de transição como pontuadores da narrativa audiovisual

Film Editing and Technology: transition effects as audiovisual punctuation

Autor: Vinicius Augusto Carvalho

Lattes: http://lattes.cnpq.br/4916633446945835

E-mail: vinicius.carvalho@espm.br

Orientador: Leonardo Marques de Abreu

Lattes: http://lattes.cnpq.br/8226912747072221

e-mail: Imarques@espm.br

\section{RESUMO}

O estudo propõe o mapeamento dos efeitos visuais de transição (fade, fusão, wipe e cluster), também chamados de pontuações visíveis em longas-metragens e tem como objetivo investigar se a revolução tecnológica dos anos 1990 impactou a utilização destes efeitos na edição fílmica. Considerando a entrada da edição não- linear na pós-produção cinematográfica, consequência do advento da tecnologia digital e dos softwares que representaram um marco na história da montagem, pretende-se analisar como evoluiu a frequência do uso de efeitos visuais de transição como reflexo da introdução da edição digital na indústria audiovisual, que simplificou o processo de aplicação destes elementos em produções imagéticas. O referencial metodológico de análise fílmica utilizado foi o modelo de Análise Textual Perceptiva de Christian Metz (2004) que sugere a necessidade de descrever o que se vê (desconstrução fílmica) antes de se interpretar algum fenômeno. A pesquisa tem como corpus todos os 83 filmes vencedores do Oscar (Academy Awards) de Melhor Montagem (Best Film Editing), concedido pela Academia de Ciências e Artes Cinematográficas dos Estados Unidos, de 1935 a 2017. Esta dissertação trata de história e tecnologia atreladas à edição, detalha cada um dos efeitos visuais de transição e, por meio de gráficos e inferências estatísticas, busca promover uma reflexão acerca do uso das pontuações visíveis em obras audiovisuais.

Palavras-chave: edição; montagem; pontuação audiovisual; efeitos de transição. 


\section{ABSTRACT}

The study proposes the mapping of transition visual effects (fade, dissolve, wipe and cluster), also called visible film punctuation in feature films in order to investigate whether the 1990s technological revolution has impacted the use of these effects in the film editing. Considering the entry of digital nonlinear editing through computers in the post-production process, due to the advent of digital technology and softwares that represent a milestone in the history of film editing, this research aims to analyze the frequency of the use of transition visual effects as a consequence of the introduction of digital editing in the film industry. The methodological process of analysis adopted in this research was the model of Perceptual Textual Analysis of Christian Metz (2004) that suggests that it is necessary to describe what is seen (film deconstruction) before seeking relationships and interpretations for the phenomena. The research features as its corpus all 83 Best Film Editing Academy Award-winning films from the Academy of Motion Picture Arts and Sciences in the United States, from 1935 to 2017. This dissertation deals with the history of editing and its technologies, details each one of the transition effects and through graphs and statistical inferences it seeks to promote some reflections on the use of visible punctuation in audiovisual products.

Keywords: film editing; film punctuation; transition effects. 